Yalova Sosyal Bilimler Dergisi

\title{
Tasarım Fakülteleri için Bir Tanıtım Önerisi: Deneyimsel Öğrenme
}

\author{
Selin ÜST ${ }^{1}$ \\ Serkan BAYRAKTAROĞLU ${ }^{2}$ \\ Çınar NARTER ${ }^{3}$
}

\begin{abstract}
Özet
Türkiye'de ilk ve orta öğretimin tek tip birey yetiştirmek üzere yapılandırılmış müfredatı, öğrencileri ilgi alanlarına yönlendirmekten ziyade üniversite sınavına odaklanmaya mecbur bırakmaktadır. Sınava odaklanan öğrencilerin meslek seçimleri genellikle sınavda aldıkları puanlara ve bu puan ile girebilecekleri bölümler arasından tesadüfler ile yapılan seçimlere dayanmaktadır.
\end{abstract}

Her ne kadar pek çok meslek eğitimi, yapısı gereği öğrencilerin ilk ve orta öğretimde edindiği bilgileri temel alarak öğrencilerin alış1k olduğu öğrenme yöntemleriyle yeni bilgi ve becerileri inşa etse de bu genellemenin dışında kalan alanlar da mevcuttur. Örneğin tasarım eğitimi genellikle tek boyutlu zihin yapısı yerine, var olanın katmanlarını anlamaya çalışan, toplumsal yaşam, fiziksel çevre ve insan ilişkisini inceleyen bir zihin yapısına sıçramayı hedefler. Tasarım eğitimi veren kurumların büyük bir kısmı liseden gelen bireylerin bu türden çoklu düşünme - öğrenme becerilerini kazanmalarını birinci yıldaki temel sanat ve tasarım ders paleti ile sağlamayı amaçlar. Daha evvel hiç karşılaşmamış olsalar bile öğrencilerin bir kısmı bu türden çoklu düşünme - öğrenme yöntemlerine kolaylıkla adapte olur. Bir kısmı ise kendi başarılı olduğu öğrenme yönteminin ötesine geçmekte zorlanır, tasarım eğitimine adapte olmakta güçlük çeker ve hatta kimi zaman vazgeçerek başka alanlara geçiş yapmak zorunda hisseder.

$\mathrm{Bu}$ noktada, lise ve üniversitelerin danışmanlık, kariyer ve tanıtım birimlerine önemli görevler düşmektedir. Öğrencilerin hem mesleği daha iyi tanımaları hem de en eğitim hayatı boyunca ihtiyaç duyacakları bakış açılarını, problem çözmede kullanacakları farklı yaklaşımları önceden deneyimlemeleri, üniversite tercihlerinde daha yerinde kararlar alabilmelerine ve kendilerini bu sürece daha iyi hazırlayabilmelerine yardımcı olacaktır. Dolayısıyla tanıtım etkinliğinin niteliği tasarım eğitimlerine geçişte kritik hale gelmektedir. Tanıtım etkinliğinin farklı tip öğrenme türlerini kapsaması halinde öğrencilerin eğitim hayatları boyunca ihtiyaç duyacakları farklı yaklaşımları bütüncül bir şekilde deneyimlemelerini sağlayabilecektir.

Makale kapsamında Kadir Has Üniversitesi tarafından Tasarım Fakültelerini hedefleyen öğrencilere yönelik düzenlenen üniversite içinde ve dışında yapılan etkinlikler araştırılmış, bu etkinlikler Deneyimsel Öğrenme Kuramı doğrultusunda öğrenci özelliklerinin gerektirdiği farklı bilişsel aşamalara göre değerlendirilmiştir.

Anahtar Kelimeler: deneyimsel öğrenme, tasarım eğitimi, tanıtım

\section{A Promotion Proposal for Design Schools: Experiential Learning}

\begin{abstract}
The primary and middle school curriculum in Turkey, structured in a manner to raise standard individuals, force students to focus on university exams rather than guiding them toward their interests. The students that focus on the entrance exams generally decide on a profession based on random choices made among the branches in which they can enroll with the scores they achieve in these exams.
\end{abstract}

\footnotetext{
${ }^{1}$ Öğr. Gör. Dr., Kadir Has Üniversitesi STF İç Mimarlık ve Çevre Tasarımı Bölümü, selin.tunali@khas.edu.tr

${ }^{2}$ Yard. Doç. Dr., Kadir Has Üniversitesi STF Endüstri Ürünleri Tasarımı Bölümü, serkan.bayraktaroglu@khas.edu.tr

${ }^{3}$ Araş. Gör., Kadir Has Üniversitesi STF Endüstri Ürünleri Tasarımı Bölümü, cnarter@khas.edu.tr
} 
Yalova Sosyal Bilimler Dergisi

Despite the fact occupational education for many professions, due to its nature, is usually built on the knowledge the students acquire in primary and middle education, and uses learning methods that the students are familiar with to equip them with new knowledge and skills, there are fields that are excluded from such generalization. For instance, design education typically aims at shifting to a mentality that attempts to understand the layers of the existing, and explores social life, physical environment and interpersonal relationships instead of a one-dimensional mindset. Most of the institutions that provide design education offer a range of basic art and design classes in the first year to endow the new high school graduates with the fundamentals and such multidimensional thinking and learning skills. Even if they have never been subjected to this approach, some of the students can easily adapt to such ways of multidimensional thinking and learning. But others may have difficulty moving beyond the learning method in which they are successful, find it challenging to adapt to design education; and at times they may even feel forced to transfer to other fields and quit.

This is where study and career counseling and publicity departments of high schools and universities should play an important role. In promoting their school, they would help the students to become more acquainted with a profession and give them a perspective they would need throughout their education, offer a chance to experience beforehand different approaches they could adopt for problem solving, to make more informed decisions for their university choices, and better prepare for the process. Therefore the quality of the activities to promote a school becomes critical in encouraging students to choose design education. Including different types of learning in the publicity efforts would ensure that the students experience different approaches they would need throughout their education in a holistic way.

Within the scope of this essay, various activities in and out of the university targeting students who are aiming for Design Faculties have been analyzed by the Kadir Has University, and these activities have been assessed in line with the Experiential Learning Theory in terms of the different cognitive stages that students with varying qualifications go through.

Keywords: experiential learning, design education, promotion

\section{Giriş}

Ülkemizde ilk ve orta öğretimin üniversite sınavı odaklı yapısı nedeniyle sorgulamayan, olanı olduğu gibi kabul eden, bilgiyi ezberleyen bireyler yetişmektedir. $\mathrm{Bu}$ bireyler, her sene liselerden mezun olarak büyük ölçüde tesadüflere bağlı olan meslek seçimlerini yapmaktadır. Kuzgun (1988)'a gençlerin ilk ve orta öğretimini bitirip meslek seçimi konusunda kararsızlık yaşadıklarından ve bütün hayatını geçirebilecekleri uğraş alanlarının seçimini yapmakta zorlandıklarından bahsetmektedir. Bu durumun günümüzde çok da iyileşmediği söylenebilir (Bozgeyikli, 2004; Akkoç, 2012; Bacanl1, 2012; Öztemel, 2012).

Meslek seçimi, genç bireyin yaşamında vermek zorunda olduğu en önemli kararlardan birini oluşturmaktadır. Sarıkaya ve Khorshid (2009), bireyin mesleğini seçerken, kendi bireysel özellikleri ile seçeceği mesleğin nitelikleri arasında bir uyum olmasına dikkat etmesi gerektiğinin üzerinde durmaktadır. Birey sahip olduğu bilgi, beceri ve taşıdığı değerleri göz önünde bulundurarak kendisine en uygun ilgi alanını seçtikten sonra seçtiği bu alanda geçmek istediği kariyer basamaklarını ve nihai hedefini belirlemelidir (Şahin ve Keser, 2016). Liseden yeni mezun olmuş bir öğrencinin ilgi duyduğu alanı seçme sürecinde güçlükler yaşaması olağan bir durumdur. Bilinçsiz seçim yapan öğrencilerin mesleki eğitim ile karşılaştıkları ilk yıl zorluk çektikleri, adapte olamadıkları hatta zaman zaman eğitimden vaz geçtikleri gözlemlenmektedir. Özellikle de ilköğretim ve lise eğitimindeki tek boyutlu zihin yapısı yerine, var olanın katmanlarını anlamaya çalışan, toplumsal yaşam, fiziksel çevre ve insan ilişkisini inceleyen bir zihin 
Yalova Sosyal Bilimler Dergisi

yapısını hedefleyen tasarım eğitimine adapte olmak oldukça güç bir süreçtir. Yoruma ve yaratıcıllğa odaklanmayan, çoktan seçmeli sınavlarla donatılmış, ezberci anlayışa sahip lise eğitiminden çıkan kararsız öğrenciler, merak eden, soru soran, tartş̧arak düşünen, akı1 yürüten öğrencilere ihtiyaç duran tasarım fakültelerine geldiklerinde zorluk yaşamaktadırlar (Bayraktaroğlu vd., 2016). Hatta Kavuran ve Polat (2016)'ın da altını çizdiği gibi, Güzel Sanatlar Liselerinden mezun öğrenciler dahi bu türden bir eğitim anlayışına geçişte büyük zorluklar çekmektedir, kendilerini yetersiz hissederek yabancılaşmaktadır.

$\mathrm{Bu}$ nedenle aday öğrenciler kariyer araştırmaları yaptıkları sırada ilerideki mesleklerini, kendilerini ve dış dünya hakkındaki bilgilerini geliştirmek için destek ihtiyaç duymaktadır. Bu destek çoğu zaman lise veya dershanelerdeki kariyer eğitim ve danışmanlık birimleri tarafından sağlansa da, son zamanlarda pek çok üniversite de tanıtım ve bilgilendirme çalışmaları ile bu sürece katkıda bulunmaktadır. Üniversiteler genellikle aday öğrencilerinin mesleki eğilimlerine bağlı olmaksızın tanıtım yapmaktadır. Kepez ve Hawks (2016) üniversitelerin tanıtım dönemlerinde yayınladıkları tam sayfa gazete tanıtımlarını incelemiş, kullanılan metin ve görsellerin çoğunlukla mesleklerin anlaşılmasına yönelik olmadığını saptamıştır. Ancak tasarım fakültelerine devam edecek öğrencilerin tasarım yapma sürecini deneyimleyebilmeleri üzerine detaylandırılmış odaklı mesleki tanıtıma ve deneyim ortamlarına ihtiyaç vardır.

$\mathrm{Bu}$ makale kapsamında Kadir Has Üniversitesi Kurumsal İletişim ve Tanıtım Biriminin üniversite içinde ve dışında lise öğrencilerine yönelik gerçekleştirdiği etkinlikler araştırılmış, bu etkinlikler öğrenci özelliklerinin gerektirdiği şekilde farklı bilişsel aşamalara göre değerlendirilmiştir.

\section{Tasarım Eğitimi ve Deneyimsel Öğrenme Modeli}

Tasarım eğitiminin ilk yılı, sorgulayan ve yaratıcı düşünmeyi öngören yeni bir eğitim sistemine öğrenciyi dâhil etmek için tam anlamıla bir geçiş basamağıdır. $\mathrm{Bu}$ yoğun ve kapsamlı ilk yılda, öğrencilerin entelektüel birikimin yanı sıra teknik beceriler de kazanabilmesi, karşılaşacakları karmaşık tasarım problemlerini çözmelerinde önem taşımaktadır. Diğer taraftan, sorgulama ve yaratıcı düşünme pratiğini kazanması hedeflenen birinci sınıf öğrencilerinin, ezbere dayalı lise eğitiminden çıktıktan sonra tasarım eğitimi ile karşılaşmaları şüphesiz ki sancılı bir süreçtir.

Birçok öğrenci için bu aşamada karşılaşılan öğrenme deneyimi sadece ilerleyen eğitim hayatlarında kullanacakları temel yetileri edinmelerinde değil, öğrencilerin mesleğe adaptasyonunda ve mesleği tanımalarında da kritik bir rol oynamaktadır. Öyle ki, ilk sene mesleki pratiklerini ilk kez ve daha yakından deneyimleyen öğrencilerin bir kısmı bölüm değiştirmeyi bir kısmı ise tamamen okuldan ayrılmayı göze alabilmektedir (Bayraktaroğlu vd., 2016).

Tasarım eğitimi boyunca öğrenciler hem teorik hem de pratik bilgiler edinir. Öğrenciler birbirlerinden farklı deneyimler ile bir süreci tamamlarlar. $\mathrm{Bu}$ süreç eğitim ile birlikte öğrencinin kendi yaşamının da içinde olduğu deneyimler 
Yalova Sosyal Bilimler Dergisi

bütününü oluşturur. Sağocak (2011)'ın da altını çizdiği gibi süreç içerisinde öğrencilerin entelektüel becerileri, hem biçimi hem de içeriği oluşturmaktadır, bu sebeple de tasarım eğitimi bir noktada öğrencinin kişisel yaşamını anlamlandırmasıdır.

Dewey (2007), öğrenme sürecini bütüncül bir deneyim olarak incelediği kitabında; biyolojik ve sosyolojik bir fenomen, yaşayan bir organizma olan öğrenenin sosyal ve doğal bir çevrenin içinde ve kendine özgü davranışlarıyla bu çevreler ile sürekli ilişki halinde olduğunun altını çizer. Yazara göre öğrenen, çevre ile ilişkilerinde ihtiyaçlarını karşılama esnasında karşılaştığı problemlerin çözümünü yine o çevre içinde bulur, ki bu da öğrenme sürecinin ta kendisidir. Öğrenmenin esasını bireylerin deneyimleme süreci ve bu deneyimleri yansıtması olarak açıklayan Kelly (1997), öğrenme aktivitesini giderek karmaşıklaşan ve derinleşen beş seviyede siralamaktadır;

- bilgiyi arttırmak

- hatırlamak, akilda tutmak

- yeni yetenekler ve yöntemler geliştirmek ve gerektiğinde kullanılmak üzere olgular elde etmek

- bilgiyi anlamlandırmak, anlamı ve bilgiyi günlük hayata eklemlemek

- edinilen bilginin yeniden yorumlanması ile dünyayı anlamlandırmak

Bilginin arttırılması ve hatırlanmasının ötesinde, edinilen bilginin anlamlandırılması, günlük hayatta kullanılması ve dünyanın anlamlandırılmasında bu bilginin yeniden yorumlanması tasarım eğitiminin de kazandırmak istediği bütüncül öğrenme biçimidir. Benzer şekilde Dewey (2007) bu durumu yaparak öğrenmek, nedensel bağlantılar kurarak kavramları ilişkilendirmek olarak tanımlar. $\mathrm{Bu}$ çerçeveden bakıldığında soyutlama becerisi kritik bir önem arz etmektedir. Soyutlama becerisi, öğrencilerin büyük bir kısmının ilk kez tasarım eğitiminin birinci sınıfında karşılaştıkları, eğitim ve mesleki hayatları boyunca sıklıkla başvuracakları bir kazanımdır. Öyle ki, edinilen bilginin yapı taşlarına ayrılıp yorumlanabilmesi ve karşılaşılacak yeni bir problemde tekrar ele alınacak şekilde yeniden şekillendirilip devreye alınabilmesi çoğu zaman kavramsal tasarım sürecinin belkemiğini oluşturmaktadır.

Talu (1999) ise sanat ve tasarım eğitiminin temelde kazandırmayı hedeflediği "anlamlı öğrenme" ye dayalı yaratıcılık anlayışını, çoklu zeka kuramı ile birlikte inceler ve öğrencilerin farklı zeka bileşenlerini tanıyabilmeleri halinde problem çözmede daha yaratıcı ve başarılı olabileceğini vurgular. Gardner'in (2004) sekiz kategoride incelediği zekâ türleri çoğu zaman farklı düşünüşs şekillerinden ve yaklaşımlarından bahseder. Birbirlerinden farklı eğilimler ve beceri etkinliklerini sergileyen bu türler arasında; dilbilimsel zekâ, müzikal zekâ, matematiksel zekâ, uzamsal zekâ, bedensel zekâ, sosyal zekâ, kişisel-içsel zekâ ve doğal zekâ sayılabilir.

Öğrenenlerin farklı zekâ türlerine sahip olabilecekleri gerçeği eğitimde kişisel farklılıkları da beraberinde getirecektir ama Talu'nun (1999) da altını çizdiği gibi belirli bir zekâ türüne sahip tasarımcı adayının eğitim süresince farklı türden 
Yalova Sosyal Bilimler Dergisi

düşünüşlerle hemhal olabilmesi onun yaratıcılığını ve problem çözme yeteneğini olumlu yönde etkileyecektir. Deneyimsel Öğrenme Modeli, farklı öğrenme türlerine vurgu yapan ve öğrenmeyi bütüncül bir şekilde ele alan bir yaklaşım olarak öne çıkmaktadır. Bu modelde Smith ve Kolb (1996) öğrenmeyi dört ana adımdan oluşan döngüsel bir süreç olarak tanımlamıştır. Bu adımlar aşağıdaki gibidir:

- somut edinim

- yansitici gözlem

- soyut kavram ve genelleme oluşturmak

- oluşan kavramların yeni durumlarda test edilmesi

Smith ve Kolb (1996)'a göre öğrenme sürecinde somut deneyimlerden oluşan gözlem ve yansımalar soyut kavram ve genelleme oluşturulmasına yol açmaktadır. Daha sonra ise oluşan kavramlar yeni koşullar altında, aktif deneylerle test edilir.

Somut edinimi deneyimden öğrenme olarak tanımladığımızda, bu süreç öğrenme özellikli tecrübelerden ve insanlarla etkileşimden oluşan bir tür farkındalıktır. Yansitıcı gözlem ya da yansıtarak öğrenme ise derinlikli incelemeler yapmak, konuları farklı perspektiflerden irdelemek ve bilişsel süreci anlamlandırmaktan oluşur. Soyut kavramsallaştırma ise düşüncelerin mantıksal analizini, sistematik planlamay1, durumun düşünsel anlayışına uygun hareket etmeyi dolayısıyla düşünerek öğrenmeyi kapsar. Oluşan kavramların yeni durumlarda test edildiği, aktif deneme aşamasında ise öğrenci riskler alarak, eyleme geçerek öğrenir.

Deneyimsel öğrenme modeli, bireyler arasındaki farkl1lıklara dayanarak öğrenme sürecinin de farklılık göstereceğini vurgular ve öğrenme stilleri kavramını ortaya atar. Öğrenme stilleri bireysel farklılıkları bir zenginlik olarak kabul ederek değişen bilgiyi alma ve zihne yerleştirme yöntemi olarak tanımlar (Smith ve Kolb, 1996). Deneyimsel öğrenme modeli öğrenmenin ideal koşullarının bu tanımlı stiller göz önünde bulundurulduğunda daha verimli olacağının altını çizer.

Piaget'in (1952) bireyin öğrenme sürecinde aktif olduğunu savunduğu bilişsel gelişim teorisinde, çocukluktan gelişkin dönemlere doğru gidildikçe deneyimlerin de etkisiyle somut olandan soyut olanın kavranabildiği bir zihinsel uyumu tanımlar. Yazar, bu süreci daha da derinlemesine irdeleyerek entelektüel gelişmenin üç aşamadan oluşan bir döngüyü takip ettiğini savunur. Buna göre; ilk aşamada birey karşılaştığı yeni bir obje ya da durumu anlamlandırmak için bilişsel olarak kendine mevcut olan bir şemayı kullanır ki bu "asimilasyon" özümseme adımıdır. İkinci adım ise "uyum kurma" dır ve birey mevcut şemanın yeni durumu tam olarak karşılamadığını fark ederek değiştirmek zorunda kalır. Son adım "dengeleme" ise bireyin başta sahip olduğu ilk hale dönmesi ve zihinsel uyumu sağlaması halidir.

Piaget (1952) ve Dewey (2007) nin yaklaşımlarından da yola çıkarak, Kolb (1984) un deneyimsel öğrenme modeline göre öğrenme, hali hazırda edinilmiş deneyimlerin bir sonucu olan, dört adımdan oluşan, kendini tekrar eden, öğrenenin aktif olduğu ve kişisel özelliklerine göre farklı bilişsel aşamalar sonunda bilgiyi zihnine yerleştirdiği bir süreç olarak tanımlanabilir. 
Tablo 1: Tasarım Eğitiminin Kolb Öğrenme Stillerine Göre Analizi

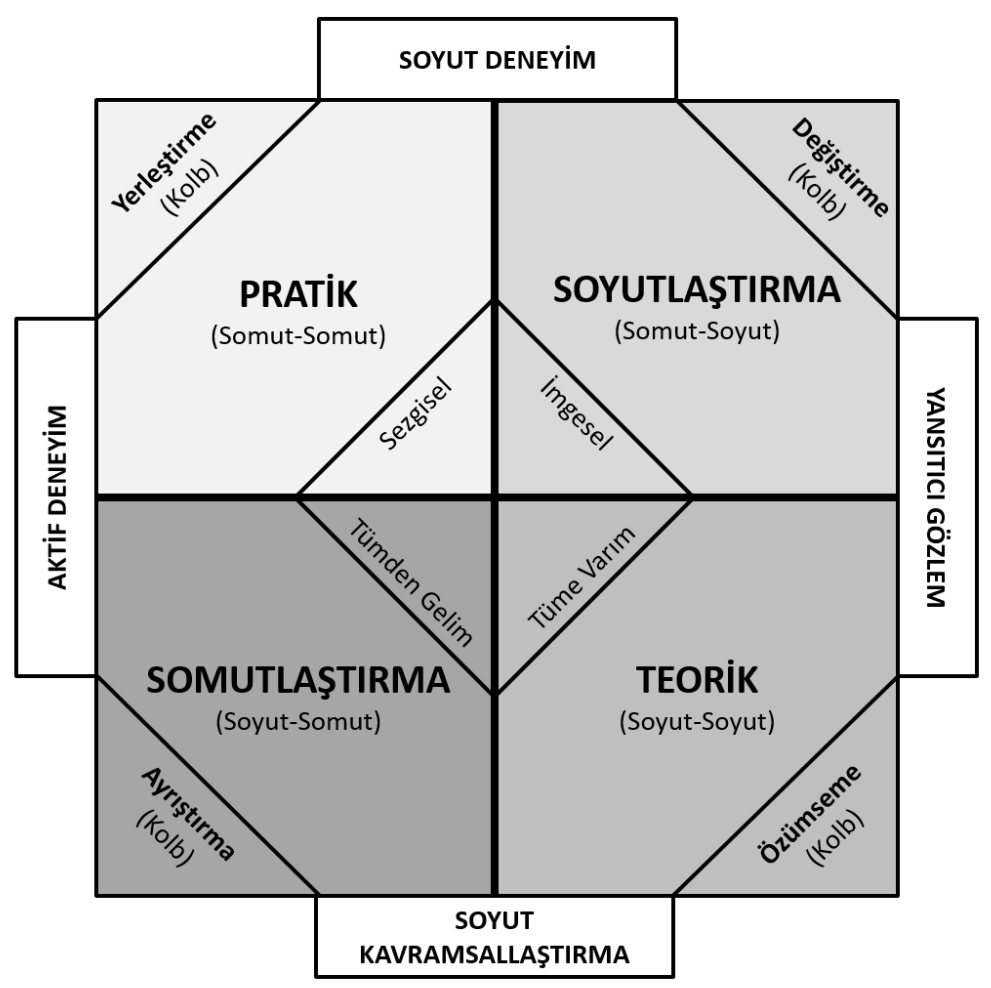

Kolb'un modeline göre kavrama, somut deneyim ve soyut kavramsallaştırmanın iki ucunda olduğu dikey eksende temsil edilir. Kavrama, somut deneyimleri kullanarak sezgisel boyutta ya da deneyimlerden oluşturulan sembolik anlamlarla gerçekleşir. Yatay çizginin iki ucundaki aktif deneyim ve yansitıcı gözlem ise bireylerin bilgiyi dönüştürme yaklaşımlarını temsil etmektedir (Kolb, 1984). Aktif deneyim ile dışsal bir etkene bağlı dönüştürme ya da yansıtıcı gözlem ile içsel yansıma sonucu oluşan dönüştürme bireyin kişisel özelliklerine göre değişebilmektedir (Yoon, 2000).

Yerleştirme (uyum kurma) yoluyla öğrenmeye yatkın bir birey çoğu zaman somut deneyimlerle öğrenir ve aktif olarak deneyler yapar. Bu kişiler genelde bir şeyleri somut olarak deneme ve yapma yolu ile bilgi edinir, problem çözmede sıklıkla deneme yanılma tekniğine başvurur.

Değiştirmeye yatkın bir öğrenen daha duygusal ve hayalcidir, somut deneyimlerle elde ettiklerini yansitıcı gözlem sonucu yeni fikirler oluşturmakta kullanır. Sistematik ilerlemez, diğer stillere nazaran daha yaratıcı yollar arar. Özümseyerek öğrenen, bilgiyi soyut kavramlar ile algılar ve yansitıcı gözlem ile işler. Bu tip ögrenenler pratik uygulamalardansa sembolik tanımlara daha yatkındırlar. Soyut kavramları dinledikleri teorik dersleri, okumaları sever, analitik modellerle ilgilenirler. 
Yalova Sosyal Bilimler Dergisi

Ayrıştırarak öğrenenler ise soyut kavramlar yolu ile algıladıklarını aktif deneyimlerle test ederler. Değiştirmeye yatkın öğrenenlere göre daha az duygusal olan bu tür öğrenenler, mantıklı, faydacı ve organizedirler. Yeni fikirlerin denenmesi, analiz edilmesi ve pratik sonuçlara varılması sıklıkla başvurdukları yöntemlerdir.

Eğitimin tüm öğrenme stillerini karşılamas1, öğrenmenin bütüncüllüğünü ve verimliliğini sağlayacaktır. Özellikle tasarım eğitimi düşünüldüğünde, öğrencilerin birden fazla öğrenme stilini gerçekleştirebilmesi onların farklı ve yaratıcı düşünebilmelerine, problem çözmede daha aktif ve verimli olabilmelerine katkıda bulunacaktır (Demirbaş ve Demirkan, 2007).

$\mathrm{Bu}$ bağlamda, lise eğitimi boyunca bir ya da iki tür öğrenme stiline adapte olmuş öğrencilerin, tasarım eğitiminin yaklaşım çeşitliliğini tasavvur edebilmesi, mesleki kariyerleri boyunca daha yaratıcı düşünebilmek için ihtiyaç duyacakları tüm bu stillere aşina olabilmesi güçtür. Lise seviyesindeki öğrencilerin bu farklı düşünüş ve öğreniş şekillerini deneyimsel öğrenmenin tabiatı gereği kitabi bir bilgi ile algılaması da çoğu zaman mümkün olmayacaktır. Bu sebeple, tasarım alanında yüksek eğitim görmek isteyen öğrencilerin meslek ve yükseköğrenim ile ilgili bilgi edinmeleri, bu süreci deneyimleyebilmeleri için gerçekleştirilecek eylemlerin deneyimsel öğrenme modelinin tarif ettiği adımları gerçekleştiriyor olması gerekecektir.

Amerika ve Avusturalya'da mimarlık mesleğini seçen öğrencilerin, üniversiteye gelmeden önce belli hazırlıklarla görsel algılarını geliştirdikleri görülürken, ülkemizde öğrencilerin bu tür bir ön hazırlığı yaparak kendilerini diğer öğrencilerden farklılaştırmadığı açıktır. Kepez (2005) Türkiye'de bir üniversitede mimarlık ve aynı puan seviyesinden öğrenci alan başka bir bölüme yerleşen 1 . sınıf öğrencileri ile yaptığı çalışmada, bu iki grubun görsel algılarında farklılık olmadığını saptamıştır. Bu anlamda Tasarım fakültelerinin 1. Sınıf dersleri, liseden yeni mezun olmuş bir öğrenci için tasarımcı olma sürecinin temellerini alması açısından önemli bir rol oynamaktadır. Türkiye'de başlıca 12 üniversitenin tasarım odaklı lisans eğitimine dair güncel 1. Sınıf ders programları arasında yapılan incelemede pek çok benzerlik dikkat çekmektedir (Bayraktaroğlu vd., 2016).

Tasarım eğitimi çok boyutlu zihin yapısı gereği Kolb (1984) un deneyimsel öğrenme kuramı ile örtüşmektedir. Tasarım eğitiminin ilk yılını Kolb’un öğrenme stillerine göre incelediğimizde, ders içeriklerinin öğrenci özelliklerinin gerektirdiği şekilde farklı bilişsel aşamalara cevap verdiği görülmektedir. Dersleri pratik, soyutlaştırma, teorik ve somutlaştırma olmak üzere dört ana kategoride altında toplamak, hangi derslerin hangi öğrenme biçimine daha çok hizmet ettiğini göstermek amacıyla yapılmış ve Tablo 2 de sunulmuştur. Bir ders, tek bir öğrenme biçimine uygun olabileceği gibi, birden çok öğrenme biçimini de destekleyebilmektedir. 
Yalova Sosyal Bilimler Dergisi

Tablo 2: Tasarım eğitimi veren programların 1.sınıf derslerinin Kolb öğrenme stillerine göre dağılımı

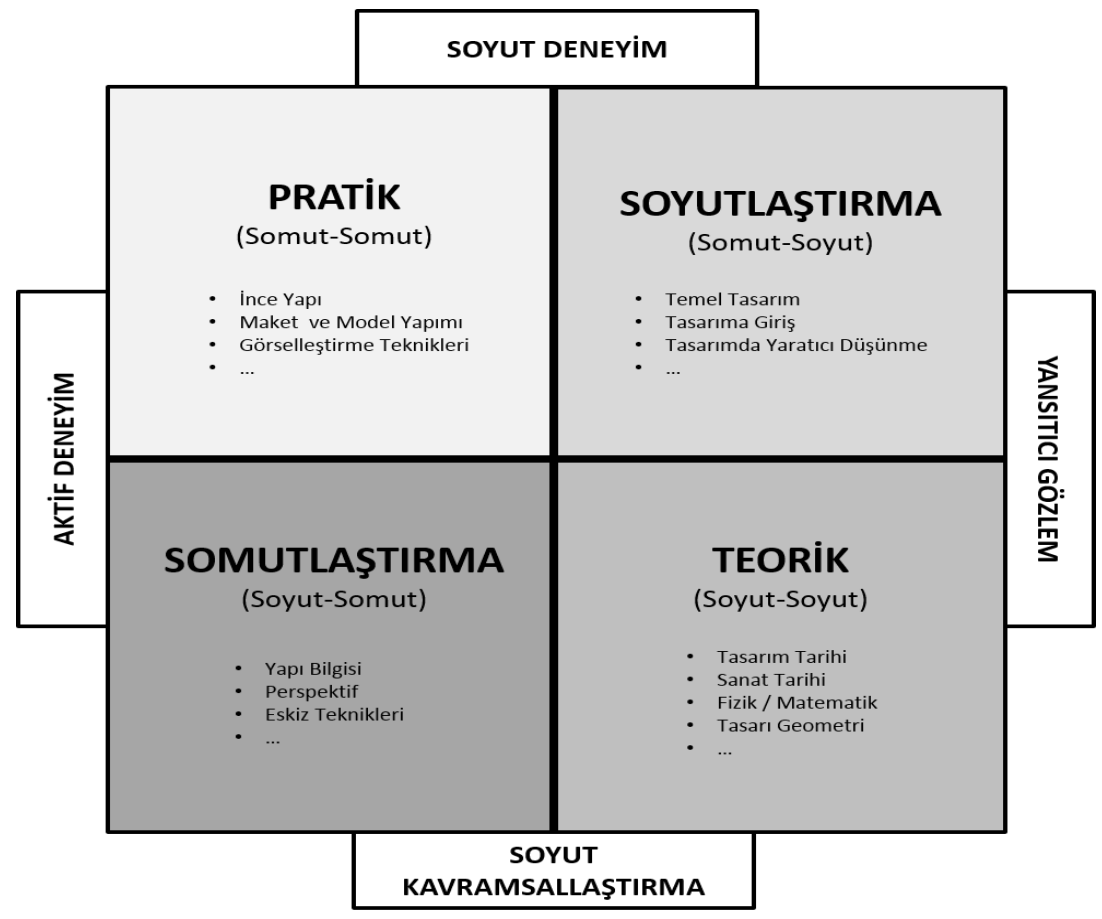

Tasarım eğitiminin birinci yılında öğrencilerin karşılaşacakları farklı bilişsel süreçlerin (pratik, soyutlaştırma, somutlaştırma ve teorik) üniversite tanıtımı etkinliklerinde de göz önünde bulundurulması, öğrencinin tasarım sürecini kavraması bağlamında tek boyutlu tanıtım faaliyetlerinden daha etkin olacaktır. Makalenin ikinci bölümünde, üniversitelerin lise öğrencilerine yönelik gerçekleştirdiği tanıtım ve rehberlik faaliyetleri deneyimsel öğrenme modeli çerçevesinde detaylı olarak incelenmiştir.

\section{2. Üniversite Eğitimi Odağında Tasarım Fakültelerine Yönelik Gerçekleştirilen Meslek Tanıtımları}

Üniversite adayları her ne kadar lise eğitimi süresince mesleki alan yönelimlerini keşfetme ve belirleme çabası içerisinde olsa da özellikle lise eğitiminin son yıllarında gerek farklı disiplinlerden öğretmenlerinin gerekse okullarının rehberlik birimlerinin katkı ve destekleri ile daha detaylı mesleki tanıtımlara katılma şansı bulabilmektedirler. Bu makale kapsamında Kadir Has Üniversitesi Kurumsal İletişim ve Tanıtım Biriminin üniversite içinde ve dışında 2010-2016 yılları arasında gerçekleştirdiği etkinlikler Eylem Araştırması, Yerinde Gözlem ve Kurumsal İletişim ve Tanıtım Birimleri ile yapılan Yarı Yapılandırılmış Görüşmeler yoluyla incelenerek Tablo 3 deki başlıklara ulaşılmıştır. 
Yalova Sosyal Bilimler Dergisi

Tablo 3:Deneyimsel Öğrenme Kuramına Göre Sınıflandırılmış Tanıtım Etkinlikleri

\begin{tabular}{|c|c|c|c|c|c|c|}
\hline & & & $\begin{array}{c}\text { PRATIK } \\
\text { (Somut-Somut) }\end{array}$ & $\begin{array}{l}\text { SOYUTLAŞTIRMA } \\
\text { (Somut-Soyut) }\end{array}$ & $\begin{array}{c}\text { TEORIK } \\
\text { (Soyut-Soyut) }\end{array}$ & $\begin{array}{l}\text { SOMUTLAŞTIRMA } \\
\text { (Soyut-Somut) }\end{array}$ \\
\hline \multicolumn{3}{|c|}{ UYGULAMA ÖZELLiĞi } & $\begin{array}{l}\text { Fiziki Etkileşim } \\
\text { Kur ve Uygula }\end{array}$ & $\begin{array}{l}\text { Fiziki Etkileşim Kur } \\
\text { ve Gözlem Yap }\end{array}$ & $\begin{array}{c}\text { Düşün ve Gözlem } \\
\text { Yap }\end{array}$ & Düşün ve Uygula \\
\hline \multicolumn{3}{|c|}{$\begin{array}{l}\text { KOLB'UN ÖĞRENME } \\
\text { STILLERI SINIFLAMASI }\end{array}$} & $\begin{array}{l}\text { Yerleştirme } \\
\text { (Accomodating) }\end{array}$ & $\begin{array}{c}\text { Değiştirme } \\
\text { (Diverging) }\end{array}$ & $\begin{array}{l}\text { Özümseme } \\
\text { (Assimilating) }\end{array}$ & $\begin{array}{l}\text { Ayrıştırma } \\
\text { (Converging) }\end{array}$ \\
\hline \multirow{8}{*}{ 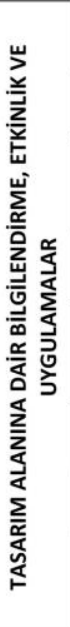 } & \multicolumn{2}{|c|}{$\begin{array}{l}\text { Üniversite Tanıtım } \\
\text { Günleri }\end{array}$} & & $\mathbf{x}$ & $\mathbf{x}$ & \\
\hline & \multicolumn{2}{|c|}{$\begin{array}{l}\text { Dışardan Gelen Liselere } \\
\text { Fakülte Tanıtımı Etkinliği }\end{array}$} & & $\mathbf{x}$ & $\mathbf{x}$ & \\
\hline & \multicolumn{2}{|c|}{$\begin{array}{l}\text { Liselere Giderek } \\
\text { Düzenlenen Kariyer } \\
\text { Günleri Etkinliği }\end{array}$} & & & $\mathbf{x}$ & \\
\hline & \multicolumn{2}{|c|}{$\begin{array}{l}\text { Liselere Giderek } \\
\text { Düzenlenen Atölyeler }\end{array}$} & $\mathbf{x}$ & $\mathbf{x}$ & $\mathbf{x}$ & $\mathbf{x}$ \\
\hline & \multicolumn{2}{|c|}{$\begin{array}{l}\text { “Üniversitede Derse } \\
\text { Girmek İster Misin" } \\
\text { Etkinliği }\end{array}$} & $\sim$ & $\mathbf{X}$ & $\mathbf{x}$ & \\
\hline & \multirow{3}{*}{$\begin{array}{l}\text { Üniversitede } \\
\text { Düzenlenen } \\
\text { Atölyeler ve } \\
\text { Yaz Kampları }\end{array}$} & $\begin{array}{l}\text { Tasarım } \\
\text { Atölyesi }\end{array}$ & $\mathbf{x}$ & $\mathbf{x}$ & $\mathbf{x}$ & $\mathbf{x}$ \\
\hline & & $\begin{array}{l}\text { Tasarım } \\
\text { Kampı }\end{array}$ & $\mathbf{x}$ & $\mathbf{x}$ & $\mathrm{x}$ & $\mathbf{x}$ \\
\hline & & $\begin{array}{l}\text { Tasarımca } \\
\text { Düşünme } \\
\text { Atölyesi }\end{array}$ & $\mathbf{x}$ & & $\mathbf{x}$ & $\mathbf{x}$ \\
\hline
\end{tabular}

$$
\mathrm{X}: \text { Var } \sim \text { : Belki }
$$

\section{1. Üniversite Tanıtım Günleri Etkinliği:}

Üniversite tanıtım günleri etkinliğinin, üniversite akademik takviminde önceden belirlenen bir tarih diliminde, Lisans Yerleştirme Sınavı (LYS) sonrası tercih yapma dönemi göz önüne alınarak kurgulandığı görülmektedir.

Üniversite tanıtım günleri kapsamında aşağıdaki aktiviteler yürütülmektedir:

- genel üniversite tanıtımları

- her bölüm tarafindan düzenlenen bölüm tanıtım seminerleri

- bölüm öğretim elemanları ve hali hazırda okuyan öğrencilerin katılımlarıyla bire bir yapılan aday bilgilendirme çalışmaları

- bire bir gerçekleştirilen tercih danışmanlığ 1

$\mathrm{Bu}$ etkinlik, üniversite sınavı sonrasında tercihlerini az çok belirlemiş olan öğrencilerin, tercih edebilecekleri üniversite ve bölümleri bizzat ziyaret ederek, buradaki öğretim elemanından bilgi alması ve sonrasında kendileri için en iyi seçimi yapmak amacı ile rehberlik hizmeti almasını içerir. Bu etkinliğin genel yapısı öncelikle katılımcıların, teorik olarak aktarılan bilgileri özümsemelerine dayanmaktadır.

Üniversite kampüsü içinde gerçekleşen bu etkinlik, katılımcıların fakülte ve bölümler ile ilgili bilgi almaları yanında üniversitenin fiziksel mekânlarını da 
Yalova Sosyal Bilimler Dergisi

görmelerini sağlamaktadır. Dolayısıyla öğrencilerin, üniversite içerisinde öğrenci olmayı somut olarak deneyimlediği ve bu deneyimden soyut varsayımlar üreterek değiştirdiği düşünülebilir.

\subsection{Dışarıdan Gelen Liselere Fakülte Tanıtımı Etkinliği:}

Üniversitenin fiziki yapısı, kültürü, mekânsal ve eğitsel olanakları, öğrenci yaşamı vb. hakkında yerinde bilgiler edinmenin öğrenci motivasyonu açısından önemli olduğu bilinmektedir. Kampüslerde yapılan toplu tanıtımlar her fakülteden bir akademisyenin fakültedeki bölümler hakkında bilgi vermesi sonrasında kampüs gezisi ile devam etmektedir.

$\mathrm{Bu}$ tür etkinliklerin zayıf yönü; etkinliklerin üniversitelerin kurumsal iletişim birimleri ile liselerdeki rehber öğretmenler arasındaki koordinasyon ile gerçekleşmesinden dolayı öğrencilerin kimi durumlarda sadece o günkü derslere girmemek için üniversite ziyaretlerine gelebilmesidir. Tanıtım etkinliğine katılmakta istekli öğrenci sayısı genele oranla az olduğu düşünülebilir.

$\mathrm{Bu}$ tür etkinliğin güçlü yanı ise ilgi düzeyi yüksek, bilinçli mesleki tercihlere yönelmiş olan öğrencilerin ilgi duydukları bölümler hakkında içerden bilgi edinme ve değerlendirme firsatı vermesi olduğu söylenebilir.

Etkinliklerde, fakültedeki tüm bölümler hakkında genel bilgi verildikten sonra her bölümün lisans eğitimi kapsamındaki dersleri ve bu derslerin genel kazanımları hakkında bilgi aktarılır. Bilgi aktaran öğretim üyesinin kişisel mesleki deneyimlerine de değindiği tanıtımların samimi bir ortamda geçtiği gözlemlenmiştir. $\mathrm{Bu}$ etkinliğin genel yapısı katılımcıların teorik olarak aktarılan bilgilerin özümseme yoluyla almalarına dayanmaktadır ve yine öğrencilerin kısmen üniversite içerisinde öğrenci olmayı somut olarak deneyimlediği ve bu deneyimden soyut varsayımlar üreterek değiş̧tirdiği düşünülebilir.

\subsection{Liselere Giderek Düzenlenen Kariyer Günleri Etkinliği:}

$\mathrm{Bu}$ etkinlikler liselerin rehberlik koordinasyon ve danışmanlık birimlerince düzenlenmektedir. Öğrenciler mesleki ilgi ve yönelimleri bakımından okullarınca belirlenen tanıtım gruplarına dahil olarak bu etkinliğe katılabilmektedirler. $\mathrm{Bu}$ etkinliklerde mesleki lisans eğitimi alanından öğretim üyeleri ilgili liseye davet edilerek mesleki bilgiler, lisans eğitimi hakkında bilgilendirmeler ve mesleki deneyimlerin aktarılması yoluyla samimi bir oturumda gerçekleşmektedir. Bu etkinliğin genel yapısı katılımcıların teorik olarak aktarılan bilgilerin özümsemesine dayanmaktadır. Önceki iki etkinlik türünün tersine öğrenci üniversite ile ilgili somut bir deneyim edinememektedir.

Bu tür etkinliklerin güçlü yanları arasında bilgi aktaran öğretim üyesinin görsel ve işitsel sunum materyalleri kullanmasına olanak sağlayan ve zaman baskısından göreceli olarak uzak olan bir yapıya sahip olması sayılabilir. 
Yalova Sosyal Bilimler Dergisi

\subsection{Liselere Giderek Düzenlenen Atölyeler:}

$\mathrm{Bu}$ tür atölyelerde, teorik anlatımlar ve uygulama birbirini tamamlayan unsurlar olduğu için katılımcısına teorik ve pratik edinimler yanında soyut düşünme ve somutlaştırma egzersizleri de yaptırabiliyor olması önemli bir çıtı olarak karşımıza çıkmaktadır. Etkinliğin genel yapısı katılımcıların teorik olarak aktarılan bilgileri özümsemesine, pratik uygulamalar ile yerleştirme ve değiştirme çalışmalarına ve ayrıştırma yoluyla bilgiyi almalarına dayanmaktadır.

$\mathrm{Bu}$ tür atölyelerin en güçlü yanı katılımcılarının herhangi bir baskı ve zorlama olmaksızın faaliyetlere gönüllülük esası ile istekli bir biçimde katılmasıdır. $\mathrm{Bu}$ durum ile atölye çalışmasının kazanımları ve çıktıları yüksek seviyede bir başarıya ulaşabilmektedir. Elde edilen kazanımlar başkaca atölyelere de bilgi kaynağı ve yöntem bilgisi aktarabildiğinden hem öğrenim kazanımı hem de yöntemsel bilgi kazanımı sağlanabilmektedir.

\section{5. “Üniversitede Derse Girmek İster Misin” Etkinliği:}

Lise öğrencilerinin mesleki eğilim ve yönelimlerini belirlemelerine 1 ş1k tutmak, kendilerine uygun meslekleri seçmelerine yardımcı olmak amacıyla "Mesleki İlgi ve Yönelim Testi" ve öğrencilerin katıldığ 1 fakülte ve bölüm bilgilendirme derslerini içeren bu etkinliğin genel yapısı, katılımcıların teorik olarak aktarılan bilgileri özümsemesi ve üniversite ortamını, öğrenci olma halini kısa süreliğine de olsa somut olarak deneyimleyerek soyut çıkarımlarda bulunup değiştirmesine dayanmaktadır. Tanıtım Günleri ve Dışarıdan Gelen Liseler için Fakülte Tanıtım Etkinliği'nin ötesinde öğrencilerin tabi olduğu test onların tercihlerini yaparken yardımcı olmaktadır.

Etkinlik kapsamında katılımcının tercih etmeyi düşündüğü veya mesleki eğilimlerine en yakın üniversite bölümünün lisans eğitimi içinde yer alan, önceden belirlenmiş bir dersine katılım yer almaktadır. Bu tür derslerin katılımcının derse kolay adapte olabilmesi için uygun kapsamda ve dilde, sunum odaklı olarak yürütüldüğü gözlemlenmiştir. Bazı durumlarda ise dersin içeriğinin uygulama egzersizleri ile donatılarak, katılımcıların somut deneyimlerden somut kazanımlar edindiği yerleştirme stilini kapsadığı saptanmıştır.

Katılımcının isteyerek katıldığı bu tür etkinliklerin güçlü yanı katılımcı ile iletişim düzeyinin yüksek olmasıdır. Ancak, öğretenden öğrenene tek yönlü bilgi akışı, öğrenme deneyiminin derinliğini azaltmaktadır. Yapılan gözlemler öğreten ve öğrenene arasındaki etkileşimin düşük olduğu, öğrencinin çekinik bir tavır sergileyerek sadece dinleyici konumunda kaldığını göstermiştir.

\subsection{Atölyeler ve Yaz Kampları:}

Çoğunlukla yaz dönemlerinde gerçekleştirilen bu etkinlikler, lise öğrencilerinin üniversite ortamını ve kapsamlı bir tasarım sürecini deneyimlemelerine firsat vermektedir. $\mathrm{Bu}$ etkinlikler üniversitelerde "Haftasonu Atölyesi / Tasarım 
Yalova Sosyal Bilimler Dergisi

Atölyesi" ya da "Tasarım Kampı" adı altında yapılmaktadır. Bu tür etkinlikler belirli bir tema, konu veya odak çerçevesinde kurgulanmaktadır.

Süreç sonunda elde edilecek kazanımlar kapsamlı bir teorik çerçevede önceden tanımlanmaktadır. Yaratıcı süreçleri barındıran bu tür atölye etkinlikleri, liselerde zorunlu hale getirilen "Teknoloji ve Tasarım" dersleri kapsamında yürütülen konulara farklı bir bakış açısı getirmektedir. Etkinlik kapsamında belirlenen görevler, kavram yaratma, soyutlama, tanımlı malzemelerle fikirlerin üçüncü boyutta temsillerinin oluşturulması ve sergilenmesi aşamalarıyla öğrencilerin lise eğitiminin ezberci ve tek tipliliğinden sıyrılmalarına yardımcı olmaktadır.

Bu etkinlikler, katılımcısını yaratıcı düşünmeye sevk eden, takım çalışması kültürü oluşturan, soyut düşünme ve soyutlama deneyimlerini yaşatan, araştırma, gözlem ve çıkarımlarda bulunmaya yönlendiren çok katmanlı bir yapıya sahiptir. Genel olarak ardışık günleri kapsayan belirli bir sürece yayılmış çalışmalardır. Örneğin; 2010 Yılında, Kadir Has Üniversitesi Cibali Kampüsü’nde, Sanat ve Tasarım Fakültesi'nce düzenlenen "Tasarım Kampı" etkinliğinde katılımcılara; öncelikle yaratıcı ve tasarım odaklı düşünmenin kazanımlarının aktarılması ve tasarlama eyleminde kullanılan yöntemlerin örnek çalışmalar üzerinden sunulması amaçlanmıştır. Öğrenciler, Haliç Altın Boynuz sahil hattı üzerinde yer alan kent dokusunun tarihi ve önemli anıtsal yapılarının inceleyerek, yapıların imge ve karakterlerini fotoğraf ve eskiz yöntemi ile tespit etmiş̧lerdir (Bayraktaroğlu vd., 2016). Bu aşamada öğrenciler kişisel deneyimleri ve ellerindeki görsel verileri kullanarak soyut kavramlar oluşturmuşlar, gözlemle elde ettikleri bilgiyi değiş̧tirmişlerdir.

Kavramlar üzerine yapılan grup tartışmalarının ardından öğrenciler, iki ve üç boyutlu malzemeler kullanılarak fikirlerini ölçekli vaziyet planı üzerinde somutlaştırmıştır. Tüm kamp süreci değerlendirildiğinde süreç içerisinde katılımcılar gözlem yapma, bakma ve görme, deşifre etme, ayrıştırma, bütünü görme, detayları inceleme, ölçek algılama, ölçekli çalışma, soyutlama ve maket yapımı konularında uygulama deneyimi yaşamışlardır.

$\mathrm{Bu}$ tür etkinliklerin genel yapısı katılımcıların teorik olarak aktarılan bilgileri özümsemesine, gözlemler yoluyla elde ettikleri verileri kullanarak kavram oluşturmasına (değiştirme), pratik uygulamalarla yeni beceriler kazanılmasına (yerleştirme) ve oluşturulan kavramları bu yeni beceriler ile somutlaştırılmasına (ayrıştırma) dayanmaktadır.

\section{Sonuç ve Öneriler}

Tasarım eğitimi farklı düşünme - öğrenme yaklaşımlarını barındıran çok katmanlı ve bütüncül bir yapıya sahiptir. Pek çok meslek eğitiminden farklı olarak, tasarım eğitimi öğrencilerin ilk ve orta öğretimde edindiği bilgileri temel alıp öğrencilerin alışı olduğu öğrenme yöntemleriyle yeni bilgi ve becerileri inşa etmesinin yanı sira öğrencileri çoklu düşünme ve öğrenme yöntemine adapte etmeyi gerektirir. Özellikle tasarım eğitiminde öğrencilerin yetkin olduğu öğrenme modeline ek olarak diğer modellerle de düşünebilmesi ve öğrenebilmesi kritik önem 
Yalova Sosyal Bilimler Dergisi

taşımaktadır. Tüm bunlar göz önünde bulundurulduğunda, tasarım eğitimine adapte olması gereken öğrencilerin bu eğitim sürecinin kapsadığı farklı öğrenme yaklaşımlarını üniversite öncesinde deneyimlemesi hem kariyer tercihi yaparken daha sağlıklı karar vermelerine, hem de seçtikleri meslek alanında başarılı olabilmelerine yardımcı olacaktır.

Tasarım eğitiminin gerektirdiği çok boyutlu zihin yapısı, Kolb (1984) un deneyimsel öğrenme kuramı ile pek çok açıdan örtüştüğü için, tasarım fakültelerini tercih etmek isteyen öğrencilerin deneyimsel öğrenme kuramında vurgulanan dört farklı bilişsel aşamayı da deneyimlemeleri yararlı olacaktır. Deneyimsel öğrenme kuramı, öğrenenin aktif olduğu ve kişisel özelliklerine göre farklı bilişsel aşamalar sonunda bilgiyi zihnine yerleştirdiği bir süreci tariflerken, dört ana öğrenme stilinden (pratik, soyutlaştırma, teorik ve somutlaştırma) bahsetmektedir. Dolayısıyla üniversitelerin tasarım fakültelerine yönelik yürütülen tanıtım etkinliklerinin deneyimsel öğrenme kuramında vurgulanan dört farklı stili de içermesi, öğrencinin ilgi duyduğu alanı seçme aşamasında yardımcı olacaktır.

$\mathrm{Bu}$ türden etkinliklerin sadece üniversitelerin tanıtım faaliyetleri kapsamında kalmayıp, orta öğretim seviyesine de adapte edilmesi, öğrencilerin farklı öğrenme stillerine yatkınlığını, soyut ve yaratıcı düşünebilme potansiyellerini ve problem çözme becerilerini geliştirebilir. Bu anlamda, ortaöğretim seviyesinde müfredata yeni eklenen tasarım ve teknoloji derslerinin içeriğinin deneyimsel öğrenme kuramının vurguladığ 1 türden bir yaklaşımla kurgulanması belirtilen ara kesitin etki alanı derinleşebilecektir.

\section{Kaynakça}

Akkoç, F. (2012). Lise Öğrencilerinin Mesleki Kararsızlıkları ile Kariyer İnançları Arasındaki İlişki. Buca Eğitim Fakültesi Dergisi, (32), 49-70.

Bacanlı, F. (2012). Kariyer Karar Verme Güçlükleri Ve Meslek Seçimine İlişkin Akılcı Olmayan İnançların İlişkisi. Türk Psikolojik Danışma ve Rehberlik Dergisi, 4(37), 86-95.

Bayraktaroğlu, S.; Üst, S.ve Narter, Ç. (2016). Lise Öğrencilerine Tasarım Eğitimi Üzerine Farkındalık Kazandırmak İçin Bir Öneri: Tasarım Kampı. Tasarım Kuram Dergisi, 11(22), 55-68.

Bozgeyikli, H. (2004). Meslek Kararı Verme Yetkinlik Ölçeğinin Geliştirilmesi. Selçuk Üniversitesi Sosyal Bilimler Enstitüsü Dergisi, (11), 221-234.

Demirbaş, O. O., ve Demirkan, H. (2007). Learning Styles of Design Students and The Relationship of Academic Performance and Gender in Design Education. Learning and Instruction, 17(3), 345-359.

Dewey, J. (2007). Deneyim ve Eğitim, çev. Sinan Akıllı, Ankara: ODTU Yayıncılık.

Gardner, H. (2004), Zihin Çerçeveleri Çoklu Zeka Kuramı, İstanbul: Alfa yayınları.

Kavuran, T., ve Polat, B. (2016). The Necessity and Significance of Basic Design Lesson in Fine Arts High Schools, Akademik Sosyal Araştırmalar Dergisi, 4(31), 452-457.

Kelly, C. (1997). David Kolb, The Theory of Experiential Learning and ESL. The Internet TESL Journal, Erişim tarihi: 17 Nisan 2017, http://www.aitech.ac.jp/ iteslj/Articles/KellyExperiential/

Kepez, O. ve Hawks, B.B. (2016). Reputation in Higher Education: Spatial Significance of University Campuses. 4th International Reputation Conference, Türkiye 16-17 Mart 2016. 
Yalova Sosyal Bilimler Dergisi

Kepez, O.(2005). Effect of Diversity of Background among Architecture Students on Perception of High ve Popular Style Houses in Design for Diversity. Proceedings of the 36th Annual Conference of the Environmental Design Research Association, Kanada, 27 Nisan - 1 Mayis 2005

Kolb, D. A. (1984). Experiential Learning: Experience as the Source of Learning and Development. Englewood Cliffs, NJ: Prentice-Hall.

Kuzgun, Y. (1988). Kendini Değerlendirme Envanteri El Kitab1, Ankara: ÖSYM Yayını.

Öztemel, K. (2012). Kariyer Kararsızlığı ile Mesleki Karar Verme Öz Yetkinlik ve Kontrol Odağı Arasındaki İlişkiler. Gazi Üniversitesi Gazi Eğitim Fakültesi Dergisi, 32(2), 459-477.

Piaget, J. (1952). The Origins of Intelligence in the Children, New York: International Universities Press.

Sağocak, M. (2011). Tasarımcı Eğitimi Üzerine Kavramsal bir Model, 1.Sanat ve Tasarım Eğitimi Sempozyumu: Dün Bugün Gelecek, Ankara, 27-29 Nisan 2011.

Sarıkaya, T. ve Khorsid, L. (2009). Üniversite Öğrencilerinin Meslek Seçimini Etkileyen Etmenlerin İncelenmesi: Üniversite Öğrencilerinin Meslek Seçimi. Türk Ĕgitim Bilimleri Dergisi, 7(2), 393-423.

Smith, D., ve Kolb, D. (1996). User Guide for the Learning Style Inventory: A Manual for Teachers and Trainers. Boston: Mc Berand Company.

Şahin, E., ve Keser, F. F. (2016). Farklılaştırılmış Eğitim Ortamlarının Öğrencilerin Meslek Algılarına Etkisi: Yasemin Karakaya Bilim ve Sanat Merkezi Örneği. Hasan Âli Yücel Eğitim Fakültesi Dergisi, 13(1), 37-48.

Talu, N. (1999), Çoklu Zeka Kuramı ve Eğitime Yansımaları, Hacettepe Üniversitesi Eğitim Fakültesi Dergisi, (15), 164 - 172.

Yoon, S.H. (2000). Using Learning Style and Goal Accomplishment Style to Predict Academic Achievement in Middle School Geography Students in Korea, Yayınlanmamış Doktora Tezi, University of Pittsburgh, Pittsburgh. 